\title{
PERAN KECUKUPAN MODAL ATAS PENGARUH RISIKO PEMBIAYAAN DAN LIKUIDITAS TERHADAP PROFITABILITAS (STUDI PADA BANK UMUM SYARIAH PERIODE 2016-2018)
}

\author{
Ryan Yushinta ${ }^{1}$ \\ Muhammad Rusdi ${ }^{2}$ \\ Lidia Desiana ${ }^{3}$ \\ Universitas Islam Negeri Raden Fatah Palembang \\ 1ryanyushinta31@gmail.com, ${ }^{2}$ dedirusdi07@gmail.com, \\ 3lidiadesiana_uin@radenfatah.ac.id
}

\begin{abstract}
This study aims to analyze and determine the influence of financing and liquidity risks on profitability with capital adequacy as an intervening variable in Islamic Commercial Banks in Indonesia for the period of 2016-2018. The population in this study were 14 Islamic Commercial Banks in Indonesia in the 2016-2018 period. The technique used in sampling is purposive sampling. The sample used is the 2016-2018 quarterly report on 7 Sharia Commercial Banks. The type of data used is secondary data. Data analysis techniques in this study used SPSS 21 software, which consisted of descriptive statistical analysis, classic assumption tests, multiple regression analysis, and mediation testing using the causal step and sobel test methods. By using multiple regression analysis, the results of the study show that the financing risk (NPF) has a negative and significant effect on profitability (ROA). Liquidity (FDR) has a positive and significant effect on profitability (ROA). Capital adequacy (CAR) doesn't affect profitability (ROA). Financing risk (NPF) has a negative and significant effect on capital adequacy (CAR). Liquidity (FDR) doesn't affect capital adequacy (CAR). Then based on the results of the analysis using the causal step and sobel test methods, capital adequacy (CAR) mediates the effect of financing risk (NPF) and liquidity (FDR) on profitability (ROA).

Keywords: Financing Risk, Liquidity, Profitability, Capital Adequacy.
\end{abstract}




\begin{abstract}
ABSTRAK
Penelitian ini bertujuan untuk menganalisis dan mengetahui pengaruh risiko pembiayaan dan likuiditas terhadap profitabilitas dengan kecukupan modal sebagai variabel intervening pada Bank Umum Syariah di Indonesia periode 2016-2018. Populasi dalam penelitian ini adalah 14 Bank Umum Syariah di Indonesia periode 2016-2018. Teknik yang digunakan dalam pengambilan sampel adalah purposive sampling. Sampel yang digunakan adalah laporan triwulanan tahun 2016-2018 pada 7 Bank Umum Syariah. Jenis data yang digunakan adalah data sekunder. Teknik analisis data dalam penelitian ini menggunakan software SPSS 21 yang terdiri dari analisis statistik deskriptif, uji asumsi klasik, analisis regresi berganda, dan pengujian mediasi dengan menggunakan metode uji kausal step dan sobel. Dengan menggunakan analisis regresi berganda, hasil penelitian menunjukkan bahwa risiko pembiayaan (NPF) berpengaruh negatif dan signifikan terhadap profitabilitas (ROA). Likuiditas (FDR) berpengaruh positif dan signifikan terhadap profitabilitas (ROA). Kecukupan modal (CAR) tidak mempengaruhi profitabilitas (ROA). Risiko pembiayaan (NPF) berpengaruh negatif dan signifikan terhadap kecukupan modal (CAR). Likuiditas (FDR) tidak mempengaruhi kecukupan modal (CAR). Kemudian berdasarkan hasil analisis menggunakan metode causal step dan sobel test, kecukupan modal (CAR) memediasi pengaruh risiko pembiayaan (NPF) dan likuiditas (FDR) terhadap profitabilitas (ROA).

Kata Kunci: Risiko Pembiayaan, Likuiditas, Profitabilitas, Kecukupan Modal.
\end{abstract}

\title{
Pendahuluan
}

Profitabilitas merupakan rasio yang menggambarkan kemampuan bank syariah dalam meraih suatu keuntungan dengan cara mengoptimalisasikan semua sumber dan kemampuan yang dimilikinya. ${ }^{1}$ Profitabilitas pada penelitian ini diproksikan dengan rasio Return on Asset (ROA), yang dimana Return On Assets merupakan suatu rasio yang menunjukkan hasil atas seluruh total aktiva yang digunakan dalam perbankan. ${ }^{2}$ Semakin besar nilai Return on Assets suatu bank syariah, maka semakin besar pula tingkat keuntungan yang akan diraih oleh bank syariah tersebut, dan semakin baik pula posisi bank syariah tersebut dari aspek

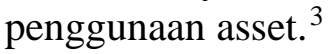

Untuk menggapai profitabilitas yang optimal, ada beragam risiko yang menjadi tantangan tersendiri bagi bank syariah, salah satunya adalah Risiko Pembiayaan. Risiko Pembiayaan merupakan suatu kondisi dimana debitur tidak mampu dalam mengembalikan pembiayaan sesuai dengan kesepakatan awal dikarenakan adanya beberapa hal yang tidak terduga. Selain Risiko Pembiayaan (NPF), ada pula risiko lain yang dapat berpengaruh terhadap Profitabilitas yaitu Likuiditas, adapun likuiditas ini didefinisikan sebagai suatu risiko yang berkaitan dengan kemampuan suatu bank syariah dalam memenuhi kewajiban

${ }^{1}$ Syafri Harahap, Sofyan. 2008. Analisa Kritis atas Laporan Keuangan. Jakarta: PT. Raja Grafindo Persada, hlm. 304.

${ }^{2}$ Kasmir. 2014. Analisis Laporan Keuangan, Edisi Satu, Cetakan Ketujuh. Jakarta: PT. Raja Grafindo Persada, hlm. 201.

${ }^{3}$ Ibid, hlm. 203. 
keuangannya yang segera harus dipenuhi. ${ }^{4}$ Rasio yang digunakan untuk mengukur likuiditas dalam penelitian ini adalah rasio Financing to Deposit Rasio (FDR). ${ }^{5}$

Faktor lainnya yang juga mempengaruhi Profitabilitas adalah Kecukupan Modal. Modal didefinisikan sebagai salah satu bagian yang sangat penting didalam suatu bank syariah, serta sebagai sumber dana utama dalam pembiayaan seluruh kegiatan operasional disuatu bank syariah. Untuk mendapatkan tingkat profitabilitas yang diharapkan, bank syariah tersebut memerlukan adanya manajemen untuk mempertahankan nilai Kecukupan Modal (Capital Adequacy Ratio) sesuai dengan kebijakan yang telah ditetapkan, apabila modal (Capital Adequacy Ratio) disuatu bank syariah termasuk ke dalam kategori cukup, maka bank syariah tersebut dapat melakukan ekspansi usaha dengan lebih aman. ${ }^{6}$ Kecukupan Modal dalam penelitian ini diproksikan dengan rasio CAR (Capital Adequacy Ratio). ${ }^{7}$

Didalam penelitian ini, Kecukupan Modal (CAR) dijadikan sebagai variabel intervening antara pengaruh Risiko Pembiayaan (NPF) dan Likuiditas (FDR) terhadap Profitabilitas (ROA) dikarenakan berbagai hal, yaitu: hal ini dikarenakan Capital Adequacy Ratio merupakan rasio permodalan yang menjadi acuan utama berjalannya kegiatan operasional disuatu bank syariah, baik dalam menghimpun dana maupun menyalurkannya kembali kepada masyarakat. Dan juga, hal ini dikarenakan menurut Muljono (1995, dalam jurnal Chairul Adhim 2018) menjelaskan bahwa variabel-variabel dalam aspek risiko pembiayaan, likuiditas dan juga profitabilitas dapat mempengaruhi permodalan disuatu bank syariah. $^{8}$ Dengan adanya beragam perbedaan dari hasil penelitian terdahulu, sehingga menjadi celah bagi peneliti untuk melakukan kajian ulang bagaimana pengaruh Risiko Pembiayaan dan Likuiditas terhadap Profitabilitas dengan Kecukupan Modal sebagai variabel intervening, serta untuk menguji pengembangan model baru, dan untuk menguji pengaruh langsung maupun tidak langsung antar variabel.

\footnotetext{
${ }^{4}$ Riyanto, Bambang. 2008. Dasar-Dasar Pembelajaran Perusahaan. BPFE: Yogyakarta, hlm. 25.

5 Weston J.Fred.dan Eugene F. Brigham. 2001. Dasar-Dasar Manajemen Keuangan. Jakarta: Erlangga, hlm. 138.

${ }^{6}$ Farida Shinta Dewi, Rina Arifati, Rita Andini. 2016. Analysis of Effect Of CAR, ROA, LDR, Company Size, NPL, and GCG to Bank Profitability (Case Study on Banking Companies Listed In BEI Period 2010-2013). Journal Of Accounting, Volume 2 No.2 Maret 2016.

${ }^{7}$ Muhamad. 2014. Manajemen Dana Bank Syariah. Yogyakarta: Raja Grafindo Persada, hlm. 257.

${ }^{8}$ Chairul Adhim. 2018. Pengaruh Risiko Kredit, Risiko Likuiditas, Efisiensi Manajemen Terhadap Profitabilitas Melalui Permodalan. Jurnal Bisnis dan Manajemen Vol. 5 No. 1, Januari, 2018, p 1-10, p-ISSN: 1829-7528, e-ISSN: 2581-1584, hlm. 3.
} 


\section{Gambar 1.1.}

\section{Perkembangan ROA secara Triwulan}

Tahun 2016-2018

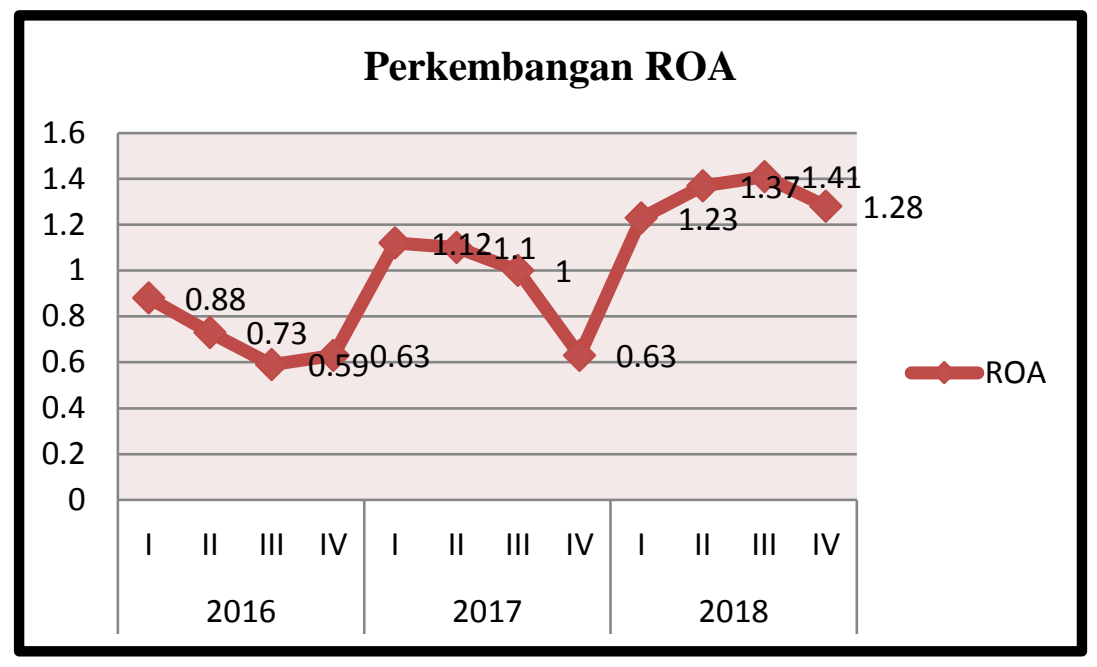

Sumber:OJK Statistik Perbankan Syariah (Laporan Keuangan diolah),2020. ${ }^{9}$

Berdasarkan gambar 1.1. diatas, menjelaskan bahwa ROA pada triwulan ke-I sampai dengan ke-IV pada tahun 2016 dan 2017 masing-masing selalu mengalami penurunan yang terus-menerus dari $0,88 \%$ sampai dengan $0,63 \%$, dan dari $1,12 \%$ menjadi $0,63 \%$, bahkan mengalami stagnan pada posisi 0,63\%. Penurunan ROA ini akan berdampak pula pada penurunan dana pihak ketiga yang akan diterima bank syariah, serta pembiayaan yang disalurkan bank syariah kepada nasabah pun akan mengalami penurunan (Nurismalatri, 2019) ${ }^{10}$.

Berdasarkan fenomena data tersebut, dapat ditarik simpulan bahwa tidak setiap kejadian empiris sesuai dengan teori yang ada. Hal ini diperkuat oleh adanya research gap dalam penelitian-penelitian terdahulu. Dengan adanya inkonsistensi hasil penelitian dan fenomena yang terjadi pada bank syariah, maka perlu diteliti lebih lanjut bagaimana pengaruh Risiko Pembiayaan dan Likuiditas terhadap Profitabilitas dengan Kecukupan Modal sebagai variabel intervening, yang diproksikan dengan rasio NPF, FDR, ROA, dan CAR.

\section{Teori Sinyal}

Teori Sinyal (signaling theory) merupakan salah satu pilar dalam memahami manajemen keuangan diperusahaan, khususnya perusahaan perbankan syariah. Sinyal ini berupa informasi yang menggambarkan mengenai apa yang sudah dilakukan oleh manajemen untuk merealisasikan keinginan pemilik. Informasi yang dikeluarkan oleh bank syariah merupakan hal yang penting, karena akan berdampak terhadap keputusan investasi pihak diluar bank syariah tersebut. ${ }^{11}$

Kinerja yang baik tercermin didalam laporan keuangan merupakan sinyal atau tanda Syariah).

${ }^{9}$ Website Otoritas Jasa Keuangan Statistik Perbankan Syariah (Laporan Keuangan Rasio Bank Umum

${ }^{10}$ Nurismalatri. 2019. Sharia Banks’ Performance in Indonesia: A Panel Model Approach. Jurnal Sekuritas, Vol.2, No.2 , Januari 2019. ISSN (online) : 2581-2777 \& ISSN (print) : 2581-2696.

${ }^{11}$ Eungene F Brigman dan Joel F Houaton. 2001. Manajemen Keuangan. Jakarta: Erlangga, hlm. 36. 
bahwa bank syariah tersebut telah beroperasi dengan baik. Sinyal yang baik akan ditanggapi dengan baik pula oleh pihak luar, karena respon pasar sangat tergantung pada sinyal fundamental yang dikeluarkan oleh bank syariah. Dengan demikian, bank syariah harus terus memberikan sinyal positif kepada para nasabah dan masyarakat, agar keyakinan penuh dan jaminan keamanan terkait dana yang telah disimpan pada bank syariah yang bersangkutan dapat diperoleh oleh nasabah. Selain itu, memberikan kerja nyata untuk membuktikan bahwa bank syariah tersebut lebih unggul dari pesaingnya, serta agar lebih dikenal oleh masyarakat luas merupakan salah satu bentuk sinyal positif yang dapat dilakukan oleh bank syariah. ${ }^{12}$

Dengan demikian, teori sinyal ini mengungkapkan bahwa semakin tinggi nilai NPF (risiko pembiayaan) pada laporan keuangan bank syariah, maka pandangan masyarakat terhadap bank syariah tersebut akan buruk, yang menandakan bahwa bank syariah belum efisien dalam mengelola manajemen keuangannya. Dan, apabila semakin tinggi nilai ROA (profitabilitas) serta CAR (kecukupan modal) maka pandangan masyarakat terhadap bank syariah tersebut akan baik, yang menandakan bahwa bank syariah tersebut telah mampu mengelola keuangannya dengan baik. Dapat disimpulkan, ketika nilai NPF (risiko pembiayaan), maka nilai ROA (profitabilitas) serta CAR (kecukupan modal) akan menurun, ini menunjukkan bahwa terdapat pengaruh negatif diantara variabel tersebut.

\section{Profitabilitas (Return on Assets)}

Profitabilitas diartikan sebagai rasio yang digunakan untuk mengukur tingkat kemampuan bank syariah dalam memperoleh keuntunganyang diharapkan. Penggunaan rasio profitabilitas (ROA) dapat dilakukan dengan menggunakan perbandingan antara berbagai komponen yang ada dilaporan keuangan, terutama laporan keuangan neraca dan laba rugi. ${ }^{13}$

Profitabilitas pada penelitian ini, diukur dengan menggunakan indikator rasio Return on Assets (ROA), dengan rumus sebagai berikut : ${ }^{14}$

$$
\text { ROA }=\frac{\text { Laba Sebelum Pajak }}{\text { Total Aktiva }} \times 100 \%
$$

\section{Risiko Pembiayaan (Non Performing Financing)}

Risiko pembiayaan didefinisikan sebagai suatu risiko yang terjadi akibat kegagalan nasabah dalam memenuhi kewajiban kepada bank syariah sesuai dengan kesepakatan awal. ${ }^{15}$ Risiko pembiayaan merupakan risiko yang wajar terjadi mengingat salah satu kegiatan operasional bank syariah adalah menyalurkan dana kepada masyarakat, atau biasa disebut dengan pembiayaan pada bank syariah. ${ }^{16}$ Untuk meminimalisir adanya risiko ini yang akan

12 Triyani.2018. Pengaruh Financing To Deposit Ratio (FDR) dan Office Channeling terhadap Profitabilitas Unit Usaha Syariah Periode 2015-2017. Skripsi Universitas Islam Negeri Raden Intan Lampung, hlm. 19.

13 Supriyono. 1999. Manajemen Biaya Suatu Reformasi Pengelolaan Bisnis Buku I Edisi I. Yogyakarta: BPFE, hlm. 56.

${ }^{14}$ Lidia Desiana, S.E, M. Si dan Aryanti, MM. 2017. Manajemen Keuangan Bank Syariah (Teori dan Evaluasi). Palembang: Penerbit Noer Fikri, hlm. 152.

15 Ismail Nawawi Uha. 2011. Manajemen Risiko. Sidoarjo: Star Safira, hlm. 37.

16 DR. Andri Soemitra,M.A. 2016. Bank dan Lembaga Keuangan Syariah Edisi Kedua. Jakarta: Kencana, hlm. 208. 
dihadapi oleh bank syariah, maka sebelum memberikan pembiayaan, bank syariah terlebih dahulu harus mengumpulkan berbagai informasi yang memadai tentang nasabah yang akan diberikan pembiayaan tersebut, salah satu contohnya adalah dengan melakukan Sistem Layanan Informasi Keuangan OJK (dulu disebut dengan BI Checking). ${ }^{17}$

Risiko pembiayaan pada penelitian ini, diukur dengan menggunakan indikator rasio Non Performing Financing (NPF), dengan rumus sebagai berikut: ${ }^{18}$

$$
\mathrm{NPF}=\frac{\text { Jumlah Pembiayaan Bermasalah }}{\text { Total Pembiayaan }} \text { 10 } \%
$$

\section{Likuiditas (Financing to Deposit Ratio)}

Rasio Likuiditas bertujuan untuk mengukur kemampuan bank syariah dalam memenuhi kewajibannya yang sudah jatuh tempo. Rasio ini menunjukkan perbandingan antara total aset lancar dengan total kewajiban lancar, serta menunjukkan kemampuan bank syariah untuk menanggulangi hutang jangka pendek dengan total aset lancar yang dimiliki. ${ }^{19}$ Tujuan utama dari rasio likuiditas yaitu sebagai pengukur untuk menilai kemampuan bank syariah dalam memenuhi kewajibannya. ${ }^{20}$

Likuiditas pada penelitian ini, diukur dengan menggunakan indikator rasio Financing to Deposit Ratio (FDR), dengan rumus sebagai berikut: ${ }^{21}$

$$
\text { FDR }=\text { Pembiayaan yang disalurkan } X 100 \%
$$
Total Dana Pihak Ketiga

\section{Kecukupan Modal (Capital Adequacy Ratio)}

Kecukupan Modal atau yang lebih dikenal dengan Capital Adequacy Ratio adalah rasio yang menggambarkan seberapa jauh seluruh aktiva bank syariah yang mengandung risiko (pembiayaan, penyertaan, surat berharga, tagihan pada bank lain) ikut dibiayai dari dana modal sendiri bank syariah disamping memperoleh dana-dana dari sumber-sumber di luar bank syariah tersebut, seperti dana dari masyarakat, pinjaman, dan lain-lain. ${ }^{22}$ Kecukupan Modal (CAR) didefinisikan sebagai indikator terhadap kemampuan bank syariah untuk menutupi penurunan aktivanya sebagai akibat dari kerugian-kerugian bank syariah yang disebabkan oleh aktiva yang berisiko. ${ }^{23}$

Kecukupan Modal pada penelitian ini, diukur dengan menggunakan indikator rasio Capital to Adequacy Ratio (CAR), dengan rumus sebagai berikut: ${ }^{24}$

${ }^{17}$ Kasmir. 2012. Bank dan Lembaga Keuangan Lainnya. Jakarta: RajaGrafindo Persada, hlm. 109.

${ }^{18}$ Ibid, hlm. 158.

${ }^{19}$ Dr. Kasmir, SE., M.M. 2011. Kewirausahaan. Jakarta: PT RajaGrafindo Persada, hlm.226.

${ }^{20}$ Lidia Desiana, S.E, M. Si dan Fernando Africano, SEI., M.Si. 2017. Analisis Laporan Keuangan (Teori dan Pemahaman Materi. Palembang: Penerbit Noer Fikri, hlm. 198.

${ }^{21}$ Lidia Desiana, S.E, M. Si dan Aryanti, MM. 2017. Manajemen Keuangan Bank Syariah (Teori dan Evaluasi). Palembang: Penerbit Noer Fikri, hlm. 158.

${ }^{22}$ Dendawijaya, Lukman. 2005. Manajemen Perbankan, Edisi Kedua, Cetakan Kedua. Jakarta: Ghalia Indonesia, hlm. 121.

${ }^{23}$ Lidia Desiana, S.E, M. Si dan Aryanti, MM. 2017. Manajemen Keuangan Bank Syariah (Teori dan Evaluasi). Palembang: Penerbit Noer Fikri, hlm. 144.

${ }^{24}$ Zainul Arifin. 2005. Dasar-Dasar Manajemen Bank Syariah. Jakarta: Pustaka Alvabet, hlm. 138. 


$$
\text { CAR }=\underline{\text { Modal }} \begin{gathered}
\text { X 100\% } \\
\text { ATMR }
\end{gathered}
$$

\section{Metode Penelitian}

Desain penelitian yang digunakan dalam penelitian ini adalah penelitian yang bersifat kausalitas dengan pendekatan kuantitatif. Populasi dalam penelitian ini adalah Laporan Triwulan periode 2016-2018 pada 14 Bank Umum Syariah yang terdaftar di Otoritas Jasa Keuangan. Teknik penentuan sampel yang digunakan dalam penelitian ini adalah purposive sampling, dilakukan dengan pertimbangan kriteria-kriteria tertentu. ${ }^{25}$ Adapun pemilihan sampel yang diambil dalam penelitian ini berdasarkan ketentuan :

\section{Tabel 1.1.}

Tahap Penyelesaian Untuk Sampel Penelitian

\begin{tabular}{|l|c|}
\hline Kriteria Pemilihan Sampel & Jumlah \\
\hline $\begin{array}{l}\text { Bank Umum Syariah yang terdaftar } \\
\text { di Otoritas Jasa Keuangan selama } \\
\text { periode 2016-2018. }\end{array}$ & 14 \\
Tidak Memenuhi Kriteria : \\
a. Bank Umum Syariah yang tidak \\
mempublikasikan Laporan \\
Keuangan Tahunannya selama \\
periode 2016-2018. \\
Bank Umum Syariah yang tidak \\
mempublikasikan Laporan \\
Keuangan Triwulan selama \\
periode 2016-2018. \\
Bank Umum Syariah yang tidak \\
menampilan rasio keuangan, \\
seperti NPF, FDR, ROA, dan \\
CAR. \\
d. Laporan Keuangan Triwulan \\
yang tidak menghasilkan Rasio \\
Keuangan terkait yang bernilai \\
positif.
\end{tabular}

Berdasarkan kriteria penentuan sampel diatas maka terdapat 7 Bank Umum Syariah yang memenuhi ketentuan, yaitu : Bank Muamalat Syariah, Bank BRI Syariah, Bank BNI Syariah, Bank Syariah Mandiri, Bank Mega Syariah, Bank BCA Syariah, dan Bank Tabungan Pensiunan Nasional Syariah.

\section{Variabel Independen (Bebas)}

Variabel independen merupakan variabel yang mempengaruhi variabel lain. ${ }^{26}$ Variabel independen yang akan diteliti pada penelitian ini adalah : Risiko Pembiayaan / Non

${ }^{25}$ Noor Juliansyah. 2011. Metodologi Penelitian: Skripsi, Tesis, Disertasi dan Karya Ilmiah. Jakarta: Kencana, hlm. 155.

${ }^{26}$ Martono, Nanang. Op.Cit, hlm. 61. 
Performing Financing (X1) dan Likuiditas / Financing to Deposit Ratio (X2).

\section{Variabel Dependen (Terikat)}

Variabel dependen merupakan variabel yang dilibatkan atau dipengaruhi oleh variabel bebas. ${ }^{27}$ Variabel Dependen yang akan diteliti pada penelitian ini adalah Profitabilitas / Return on Assets (Y).

\section{Variabel Intervening}

Variabel Intervening adalah variabel yang secara teoritis mempengaruhi hubungan antara variabel independen dengan dependen, tetapi tidak dapat diamati dan diukur. ${ }^{28}$ Dalam penelitian ini, variabel intervening yaitu Kecukupan Modal / Capital Adequacy Ratio (M).

Metode analisis data dalam penelitian ini menggunakan teknik analisis jalur (path analysis) dengan bantuan program SPSS 21.

$M($ KECUKUPAN MODAL $)=\beta$ RISIKO PEMBIAYAAN $+\beta$ LIKUIDITAS + e1 (Persamaan Struktural 1)

$\mathrm{Y}($ PROFITABILITAS $)=\beta$ RISIKO PEMBIAYAAN $+\beta$ LIKUIDITAS + BKECUKUPAN MODAL + e1 (Persamaan Struktural 2)

\section{Teknik Analisis Data}

\section{Uji Asumsi Klasik}

\section{a. Uji Normalitas}

Uji normalitas bertujuan untuk menguji apakah dalam sebuah model regresi, variabel pengganggu dan residual atau variabel dependen dan independen memiliki distribusi normal atau tidak. Uji normalitas pada penelitian ini diuji dengan uji statistik Jarque-Bera (JB Test) yang dilakukan dengan membandingkan statistik Jarque-Bera (JB) dengan nilai Chi Square tabel. Dengan uji statistik yaitu menggunakan uji statistik non-parametik Jarque-Bera Test.

Jika nilai Jarque-Bera (JB) < Chi Square tabel, maka nilai residual terstandarisasi dinyatakan berdistribusi " normal “. Untuk menghitung nilai statistik Jarque-Bera (JB) digunakan rumus sebagai berikut : ${ }^{29}$

$$
J B=n\left(\frac{S^{2}}{6}+\frac{(K-3)^{2}}{24}\right)
$$

Keterangan :

$\mathrm{JB}=$ Statistik Jarque-Bera

$\mathrm{S} \quad=$ Koefisien Skewness

$\mathrm{K} \quad=$ Koefisien Kurtosis

\section{b. Uji Multikolinearitas}

Uji multikolinieritas bertujuan untuk menguji apakah model regresi ditemukan adanya korelasi antar variabel bebas. Model regresi yang baik seharusnya tidak terjadi korelasi di antara variabel independen.

Uji Multikolinearitas yang digunakan adalah dengan menggunakan metode Nilai

${ }^{27}$ Ibid, hlm. 61.

${ }^{28}$ Sugiyono. 2014. Metode Penelitian Kuantitatif, Kualitatif dan R\&D. Bandung: Alfabeta, hlm. 61.

${ }^{29}$ Dr. Suliyanto. 2011. Ekonometrika Terapan: Teori \& Aplikasi dengan SPSS. Yogyakarta: Penerbit ANDI, hlm. 75. 
Pair-Wise Correlation antar Variabel Bebas, yaitu dengan melihat nilai koefisien korelasi antar variabel bebas tidak lebih dari 0,70 atau lebih besar dari -0,70, maka model ini tidak mengandung gejala multikolinearitas. ${ }^{30}$

\section{c. Uji Heteroskedastisitas}

Heteroskedastisitas adalah alat uji yang bertujuan untuk menguji apakah dalam model regresi terjadi ketidaksamaan varian dari residual satu pengamatan ke pengamatan yang lain. ${ }^{31}$ Jika varian dari satu pengamatan ke pengamatan yang lain tetap, maka disebut heteroskedastisitas. Model regresi yang baik adalah homoskedastisitas atau tidak terjadi heteroskedastisitas.

Salah satu cara untuk mendeteksi ada atau tidaknya heteroskedastisitas adalah dengan metode White, dilakukan dengan cara meregresikan semua variabel bebas, variabel bebas kuadrat, dan perkalian variabel bebas terhadap nilai residual kuadratnya. Jika nilai Chi Square Hitung > Chi Square Tabel dengan $\mathrm{df}=\mathrm{n}-\mathrm{k}$, jumlah variabel bebas, maka dalam model terdapat masalah heterokedastisitas. Nilai Chi Square hitung dalam metode ini diperoleh dari $\mathrm{n} \times \mathrm{R}^{2}$, dimana $\mathrm{n}=$ jumlah sampel, sedangkan $\mathrm{R}^{2}=$ koefisien determinasi regresi tahap kedua. Dapat dinyatakan tidak terjadi heterokedastisitas apabila Chi Square Hitung < Chi Square Tabel. ${ }^{32}$

\section{d. Uji Autokorelasi}

Uji Autokorelasi bertujuan untuk mengetahui apakah ada korelasi antara anggota serangkaian data observasi yang diuraikan menurut waktu (time series). Uji autokorelasi yang digunakan dalam penelitian ini adalah metode Lagrange Multiplier (LM Test). Dengan menghitung nilai Chi Square Hitung hitung dengan rumus sebagai berikut: ${ }^{33}$

$$
\text { Chi Square Hitung }=\mathrm{n} \times \mathrm{R}^{2}
$$

Pada model persamaan regresi, dapat dinyatakan "tidak terjadi autokorelasi“" apabila Chi Square Hitung < Chi Square Tabel.

\section{e. Uji Linearitas}

Uji linearitas bertujuan untuk mengetahui apakah dua variabel mempunyai hubungan yang linear atau tidak secara signifikan. Uji ini biasanya digunakan sebagai prasyarat dalam analisis korelasi atau regresi linear. Pengujian dengan SPSS dengan menggunakan Metode Ramsey. Metode Ramsey mengasumsikan bahwa metode yang benar adalah persamaan yang linear sehingga hipotesis nol menyatakan bahwa model adalah linear. Sebaliknya, hipotesis alternatif menyatakan bahwa model adalah tidak linear. Prinsip metode Ramsey adalah membandingkan antara nilai $\mathrm{F}$ hitung dengan nilai $\mathrm{F}$ tabel, dengan $\mathrm{df}=\alpha, \mathrm{m}, \mathrm{n}-\mathrm{k}$. Untuk menghitung nilai $\mathrm{F}$ hitung, dapat dilakukan dengan persamaan sebagai berikut $:^{34}$

\footnotetext{
${ }^{30}$ Ibid, hlm. 85.

31 Ghozali, Imam. Model Persamaan Structural Konsep dan Aplikasi dengan Program AMOS Ver. 5.0. Semarang: Badan Penerbit Universitas Diponegoro, hlm. 105.

${ }^{32}$ Dr. Suliyanto. 2011. Ekonometrika Terapan: Teori \& Aplikasi dengan SPSS. Yogyakarta: Penerbit

${ }^{33}$ Ibid, hlm. 125.

${ }^{34}$ Ibid, hlm. 164.
} ANDI, hlm. 102. 


$$
\mathrm{F}=\frac{\left(\mathrm{R}^{2}{ }_{\text {new }}-\mathrm{R}^{2}{ }_{\text {old }}\right) / \mathrm{m}}{\left(1-\mathrm{R}^{2}{ }_{\text {new }}\right) /(\mathrm{n}-\mathrm{k})}
$$

\section{Keterangan :}

$\mathrm{m} \quad=$ jumlah variabel bebas yang baru masuk

$\mathrm{n} \quad=$ jumlah sampel

$\mathrm{k} \quad$ = banyaknya parameter

Dapat dinyatakan “ linear “, jika telah memenuhi kriteria $\mathrm{F}$ hitung $<\mathrm{F}$ tabel dengan $\mathrm{df}=(\alpha, \mathrm{m}, \mathrm{n}-\mathrm{k})$.

\section{Analisis Regresi Berganda}

\section{a. Analisis Substruktur Persamaan 1}

\section{1) Persamaan Regresi Berganda}

Persamaan regresi berganda digunakan untuk menggambarkan model hubungan antar variabel bebas dengan variabel tergantungnya. Persamaan regresi ini berisikan nilai konstanta atau intercept nilai koefisien regresi atau slope dan variabel bebasnya. Dengan persamaan sebagai berikut : ${ }^{35}$

\section{$\mathrm{M}($ KECUKUPAN MODAL $)=\beta$ RISIKO PEMBIAYAAN $+\beta$ LIKUIDITAS + e1 (Persamaan Struktural 1)}

\section{2) Uji F}

Uji F hitung digunakan untuk menguji ketepatan model serta untuk menguji pengaruh secara simultan variabel bebas terhadap variabel tergantungnya. Jika variabel bebas memiliki pengaruh secara simultan terhadap variabel tergantung maka model persamaan regresi masuk dalam kriteria cocok atau fit. Sebaliknya, jika terdapat pengaruh secara simultan maka masuk dalam kategori tidak cocok atau not fit. Suatu variabel dianggap berpengaruh jika F hitung $>$ F tabel, dan dinyatakan signifikan apabila nilai Sig. $<0,05 .^{36}$

\section{3) Uji t}

Nilai t hitung digunakan sebagai alat untuk menguji pengaruh secara parsial (per variabel) terhadap variabel tergantungnya. Apakah variabel tersebut memiliki pengaruh yang berarti terhadap variabel tergantungnya atau tidak. Suatu variabel dianggap berpengaruh jika thitung $>\mathrm{t}$ tabel, dan dinyatakan signifikan apabila nilai Sig. $<0,05 .^{37}$

\section{4) Koefisien Determinasi $\left(\mathbf{R}^{2}\right)$}

Koefisien Determinasi adalah besarnya kontribusi variabel tergantungnya. Semakin tinggi koefisien determinasi, maka semakin tinggi kemampuan variabel bebas dalam menjelaskan variasi perubahan pada variabel tergantungnya. ${ }^{38}$

Persamaan Struktural 1 : M (KECUKUPAN MODAL) $=\beta$ RISIKO PEMBIAYAAN + $\beta$ LIKUIDITAS + e1

Untuk mengetahui pengaruh Risiko Pembiayaan dan Likuiditas terhadap

\footnotetext{
${ }^{35}$ Ibid, hlm. 154.

${ }^{36}$ Ibid, hlm. 162.

${ }^{37}$ Ibid, hlm. 155.

${ }^{38}$ Ibid, hlm. 160.
} 
Kecukupan Modal secara simultan adalah dari hasil perhitungan dalam model summary, khususnya angka Adjusted $R$ square yang digunakan untuk mengetahui besarnya pengaruh Risiko Pembiayaan dan Likuiditas terhadap Kecukupan Modal dengan cara menghitung koefisien determinasi (KD) menggunakan rumus :

$$
\mathrm{KD}=\operatorname{Adj} \mathrm{R}^{2} \text { x } 100 \%
$$

\section{b. Analisis Substruktur Persamaan 2}

\section{1) Persamaan Regresi Berganda}

Persamaan regresi berganda digunakan untuk menggambarkan model hubungan antar variabel bebas dengan variabel tergantungnya. Persamaan regresi ini berisikan nilai konstanta atau intercept nilai koefisien regresi atau slope dan variabel bebasnya. Dengan persamaan sebagai berikut : ${ }^{39}$

$\mathrm{Y}($ PROFITABILITAS $)=\beta$ RISIKO PEMBIAYAAN $+\beta$ LIKUIDITAS + BKECUKUPAN MODAL + el (Persamaan Struktural 2)

\section{2) Uji F}

Uji F hitung digunakan untuk menguji ketepatan model serta untuk menguji pengaruh secara simultan variabel bebas terhadap variabel tergantungnya. Jika variabel bebas memiliki pengaruh secara simultan terhadap variabel tergantung maka model persamaan regresi masuk dalam kriteria cocok atau fit. Sebaliknya, jika terdapat pengaruh secara simultan maka masuk dalam kategori tidak cocok atau not fit. Suatu variabel dianggap berpengaruh jika F hitung $>$ F tabel, dan dinyatakan signifikan apabila nilai Sig. $<0,05 .^{40}$

3) Uji t

Nilai t hitung digunakan sebagai alat untuk menguji pengaruh secara parsial (per variabel) terhadap variabel tergantungnya. Apakah variabel tersebut memiliki pengaruh yang berarti terhadap variabel tergantungnya atau tidak. Suatu variabel dianggap berpengaruh jika t hitung $>\mathrm{t}$ tabel, dan dinyatakan signifikan apabila nilai Sig. $<0,05 .{ }^{41}$

\section{4) Koefisien Determinasi $\left(R^{2}\right)$}

Koefisien Determinasi adalah besarnya kontribusi variabel tergantungnya. Semakin tinggi koefisien determinasi, maka semakin tinggi kemampuan variabel bebas dalam menjelaskan variasi perubahan pada variabel tergantungnya. ${ }^{42}$

\section{Persamaan Struktural 2 : Y (PROFITABILITAS) $=\beta R I S I K O$ PEMBIAYAAN + $\beta$ LIKUIDITAS + $\beta$ KECUKUPAN MODAL + e1}

Untuk mengetahui pengaruh Risiko Pembiayaan, Likuiditas, dan Kecuukupan Modal terhadap Profitabilitas secara simultan adalah dari hasil perhitungan dalam model summary, khususnya angka Adjusted $R$ square yang digunakan untuk mengetahui besarnya pengaruh Risiko Pembiayaan, Likuiditas, dan Kecukupan Modal secara simultan terhadap Profitabilitas dengan cara menghitung koefisien

\footnotetext{
${ }^{39}$ Ibid, hlm. 154.

${ }^{40}$ Ibid, hlm. 162.

${ }^{41}$ Ibid, hlm. 155.

${ }^{42}$ Ibid, hlm. 160.
} 
determinasi (KD) menggunakan rumus:

$$
\mathrm{KD}=\operatorname{Adj} \mathrm{R}^{2} \text { x } 100 \%
$$

\section{Uji Mediasi}

Untuk menguji pengaruh variabel intervening digunakan metode causal step . Menurut Ghozali, uji mediasi merupakan perluasan analisis regresi linear berganda atau uji mediasi adalah penggunaan analisis regresi untuk menaksir hubungan kausalitas antar variabel (model causal) yang telah ditetapkan sebelumnya berdasarkan teori. ${ }^{43}$ Sedangkan menurut Noor, uji mediasi adalah keterkaitan hubungan/pengaruh antara variabel bebas, variabel intervening dan variabel terikat dimana peneliti mendefinisikan secara jelas bahwa suatu variabel akan menjadi penyebab variabel lainnya yang biasa disajikan dalam bentuk diagram. ${ }^{44}$ Teknik analisis jalur menggambarkan keterkaitan regresi berganda dengan variabel yang hendak diukur.

\section{a. Causal Step}

Analisis variabel mediasi Baron dan Kenny ${ }^{45}$ yang lebih dikenal dengan strategy causal step, memiliki tiga persamaan regresi yang harus diestimasi, yaitu: ${ }^{46}$

1) Persamaan regresi sederhana variabel mediator (M) pada variabel independen (X) yang diharapkan variabel independen signifikan mempengaruhi variabel mediator, jadi koefisien $a \neq 0$.

2) Persamaan regresi sederhana variabel dependen $(Y)$ pada variabel independen (X) yang diharapkan variabel independen harus signifikan mempengaruhi variabel, jadi koefisien $\mathrm{c} \neq 0$.

3) Persamaan regresi berganda variabel dependen $(Y)$ pada variabel independen $(X)$ dan mediator $(\mathrm{M})$ yang diharapkan variabel mediator signifikan mempengaruhi variabel dependen, jadi koefisien $b \neq 0$.

Mediasi terjadi jika pengaruh variabel independen terhadap variabel dependen lebih rendah pada persamaan ketiga (c') dibandingkan pada persamaan kedua (c). Sebenarnya koefisien a dan b yang signifikan sudah cukup untuk menunjukkan adanya mediasi, meskipun c tidak signifikan. Sehingga tahap esensial dalam pengujian emosional adalah step 1 dan step 3. Jadi (1) variabel independen mempengaruhi mediator dan (2) mediator mempengaruhi dependen meskipun independen tidak mempengaruhi dependen. Bila step 1 dan step 3 terpenuhi dan koefisien c tidak signifikan ( $\mathrm{c}=0$ ) maka terjadi perfect atau complete atau full mediation. Bila koefisien c' berkurang namun tetap signifikan $\left(c^{\prime} \neq 0\right)$ maka dinyatakan terjadi partial

${ }^{43}$ Ghozali, Imam. 2007. Aplikasi Analisis Multivariate dengan Program SPSS. Semarang: UNDIP, hlm. 174.

${ }^{44}$ Noor, Juliansyah. 2011. Metodologi Penelitian: Skripsi, Tesis, Disertai dan Karya Ilmiah. Jakarta: Kencana Prenada Media group, hlm. 265.

${ }^{45}$ Baron, R. M and Kenny, D. A. "The Moderator-Mediator Variable Distinction In Social Psychological Research: Conceptual Strategic and Statistical Considerations.”Journal of Personality and Social Psychologi. Vol. 51, No. 6, 1173-1182. Americal Pshcological Association, Inc. 1986.

${ }^{46}$ Dr. Suliyanto. 2011. Ekonometrika Terapan: Teori \& Aplikasi dengan SPSS. Yogyakarta: Penerbit ANDI, hlm. 194. 
mediation. ${ }^{47}$

Terdapat 3 (tiga) model analisis yang melibatkan variabel mediator, diantaranya sebagai berikut:

1) Perfect atau Complete atau Full Mediation, artinya variabel independen (Risiko Pembiayaan dan Likuiditas) tidak mampu mempengaruhi secara signifikan variabel dependen (Profitabilitas) tanpa melalui variabel mediator (Kecukupan Modal).

2) Partial Mediation, artinya variabel independen (Risiko Pembiayaan dan Likuiditas) mampu mempengaruhi secara langsung varaiabel dependen (Profitabilitas) maupun tidak langsung dengan melibatkan variabel mediator (Kecukupan Modal).

3) Ummediated, artinya variabel independen (Risiko Pembiayaan dan Likuiditas) mampu mempengaruhi secara langsung variabel dependen (Profitabilitas) tanpa melibatkan variabel mediator (Kecukupan Modal).

Baroon dan Kenny menjelaskan prosedur analisis variabel mediator secara sederhana melalui analisis regresi. Dan dapat dilakukan dengan analisis regresi sebanyak 3 (tiga) kali. ${ }^{48}$

1) $X$ memprediksi $Y$

Analisis regresi ini akan menghasilkan nilai estimator prediktor (di SPSS simbolnya juga B). Kita namakan nilai ini dengan rumus jalur c. Jalur ini nilainya diharapkan signifikan $(\mathrm{P}<\alpha=0,05)$.

2) $\mathrm{X}$ memprediksi $\mathrm{M}$

Analisis regresi ini akan menghasilkan nilai estimator prediktor (di SPSS simbolnya juga B). Kita namakan nilai ini dengan rumus jalur a. Jalur ini nilainya diharapkan juga signifikan $(\mathrm{P}<\alpha=0,05)$.

3) $\quad \mathrm{M}$ memprediksi $\mathrm{Y}$ (mengestimasi DV dengan mengendalikan IV)

Dengan menganalisis efek M dan X terhadap Y. Masukkan X dan M sebagai prediktor terhadap Y. Analisis regresi ini akan menghasilkan dua nilai estimasi prediktor dari $\mathrm{M}$ dan $\mathrm{X}$. Prediksi nilai $\mathrm{M}$ terhadap $\mathrm{Y}$ kita namakan jalur b, sedangkan prediksi nilai X terhadap Y kita namakan jalur c'. Jalur b nilainya diharapkan signifikan, sedangkan jalur c’ nilainya diharapkan tidak signifikan.

Jadi empat tahapan prosedurnya analisisnya, yaitu:

1) Mengestimasi jalur c : meregresikan $Y$ dengan $X$ sebagai prediktor.

2) Mengestimasi jalur a : meregresikan $M$ dengan $X$ sebagai prediktor.

3) Mengestimasi jalur $\mathrm{b}:$ meregresikan $\mathrm{Y}$ dengan $\mathrm{M}$ sebagai prediktor.

4) Mengestimasi jalur c' : meregresikan $Y$ dengan $X$ dan $M$ sebagai prediktor. Intinya menurut Baron dan Kenny ${ }^{49}$, sebuah variabel dapat dikatakan menjadi mediator jika hasilnya:

1) Jalur c : signifikan

2) Jalur a : signifikan

${ }^{47}$ Preacher, K. J., Rucker, D. D and Hayes, A. F. “ Addressing Moderated Mediation Hypothesis: Theory, Methods and Prescriptions”. (Multivariate Behavioral Research, 42(1), 185227.Lawrence Erlbaum Associates, Inc. 2007).

${ }^{48}$ Dr. Suliyanto. 2011. Ekonometrika Terapan: Teori \& Aplikasi dengan SPSS. Yogyakarta: Penerbit ANDI, hlm. 194.

${ }^{49}$ Ibid. 
3) Jalur b : signifikan

4) Jalur c' : signifikan

\section{Hasil Penelitian}

\section{Analisis Substruktur}

$M($ KECUKUPAN MODAL $)=\beta$ RISIKO PEMBIAYAAN $+\beta$ LIKUIDITAS + e 1 (Persamaan Struktural 1)

$\mathrm{Y}($ PROFITABILITAS $)=\beta$ RISIKO PEMBIAYAAN $+\beta$ LIKUIDITAS + BKECUKUPAN MODAL + e1 (Persamaan Struktural 2)

Tabel 1.2.

Pengaruh Persamaan Struktural 1 dan Persamaan Struktural 2

\begin{tabular}{|c|c|}
\hline Persamaan Struktural 1 & Persamaan Struktural 2 \\
\hline Adjusted $R$ Square & Adjusted $R$ Square \\
\hline 0,299 & 0,364 \\
\hline
\end{tabular}

Besarnya pengaruh Risiko Pembiayaan (NPF) dan Likuiditas (FDR) terhadap Kecukupan Modal (CAR) adalah 29,9\%. Besarnya pengaruh Risiko Pembiayaan (NPF), Likuiditas (FDR), dan Kecukupan Modal (CAR) terhadap Profitabilitas (ROA) adalah $36,4 \%$.

Tabel 1.3.

Uji t Persamaan Struktural 1

Pengaruh NPF dan FDR Terhadap CAR

\begin{tabular}{|l|l|c|c|}
\hline \multicolumn{3}{|c|}{ Coefficients $^{a}$} \\
\hline \multicolumn{2}{|l|}{ Model } & $\mathrm{t}$ & Sig. \\
\hline \multirow{2}{*}{1} & (Constant) & 1.492 & .140 \\
\cline { 2 - 4 } & X1_NPF & -4.624 & .000 \\
\cline { 2 - 4 } & X2_FDR & 1.510 & .135 \\
\hline \multicolumn{3}{|c|}{ a. Dependent Variable: M_CAR } \\
\hline
\end{tabular}

Didasarkan hasil perhitungan, diperoleh hasil penelitian nilai -t hitung $<-t$ tabel ($4,624<-1,66388)$ dan nilai signifikansi sebesar 0,000 < 0,05, maka dapat disimpulkan bahwa Risiko Pembiayaan (NPF) berpengaruh negatif dan signifikan terhadap Kecukupan Modal (CAR) pada 7 Bank Umum Syariah periode 2016-2018. Semakin besar risiko pembiayaan yang dihadapi suatu bank syariah, akan berdampak terhadap peningkatan pembentukan cadangan Penyisihan Penghapusan Aktiva Produktif (PPAP) dari modal yang dimiliki, sehingga berkurangnya bagian dari modal yang merupakan komponen kecukupan modal. Dengan demikian hubungan Risiko Pembiayaan (NPF) terhadap Kecukupan Modal (CAR) adalah negatif dan signifikan. ${ }^{50}$ Hal ini diperkuat dengan hasil penelitian yang

${ }^{50}$ Fernando Africano. Pengaruh NPF Terhadap CAR Serta Dampaknya Terhadap Profitabilitas Bank Umum Syariah Di Indonesia. Forum Bisnis Dan Kewirausahaan Jurnal Ilmiah STIE MDP Vol. 6 No. 1 September 2016, hlm. 68. 
dilakukan oleh Fernando Africano ${ }^{51}$, serta Komang Triska Ariwidanta ${ }^{52}$.

Didasarkan hasil perhitungan, diperoleh hasil penelitian nilai t hitung $<\mathrm{t}$ tabel $(1,510$ $<$ 1,66388) dan nilai signifikansi sebesar 0,135 > 0,05, maka dapat disimpulkan bahwa Likuiditas (FDR) tidak berpengaruh terhadap Kecukupan Modal (CAR) pada 7 Bank Umum Syariah periode 2016-2018. Jika semakin besar nilai FDR (likuiditas), mengindikasikan jumlah pembiayaan yang diberikan oleh bank syariah kepada masyarakat pun lebih besar, dengan begitu maka akan meningkatkan profitabilitas bank syariah, yang dimana akan dialokasikan kepada modal bank syariah tersebut, sehingga semakin besar CAR (kecukupan modal) yang akan diperoleh oleh Bank Syariah. FDR (likuiditas) berpengaruh positif terhadap tingkat CAR (kecukupan modal). Semakin tinggi nilai FDR (likuiditas), maka akan berdampak pada meningkatnya CAR (kecukupan modal) bank umum syariah. ${ }^{53}$ Hal ini diperkuat dengan hasil penelitian yang dilakukan oleh Ni Putu Sinta Wira Putri dan I Made Dana $^{54}$.

Tabel 1.4.

Uji t Persamaan Struktural 2

Pengaruh NPF, FDR, dan CAR Terhadap ROA

\begin{tabular}{|l|l|c|c|}
\hline \multicolumn{3}{|c|}{ Coefficients $^{a}$} \\
\hline \multicolumn{2}{|l|}{ Model } & $\mathrm{t}$ & Sig. \\
\hline \multirow{2}{*}{1} & (Constant) & -1.432 & .156 \\
\cline { 2 - 4 } 1 & $\mathrm{X} 1$ _NPF & -3.258 & .002 \\
\cline { 2 - 4 } & X2_FDR & 2.131 & .036 \\
\cline { 2 - 4 } & M_CAR & 1.868 & .065 \\
\hline \multicolumn{3}{|c|}{ a. Dependent Variable: Y_ROA } \\
\hline
\end{tabular}

Didasarkan hasil perhitungan, diperoleh hasil penelitian nilai -t hitung $<$-t tabel $(-$ $3,258<-1,66412$ ) dan nilai signifikansi sebesar 0,002 <0,05, maka dapat disimpulkan bahwa Risiko Pembiayaan (NPF) berpengaruh negatif dan signifikan terhadap Profitabilitas (ROA) pada 7 Bank Umum Syariah periode 2016-2018. Risiko Pembiayaan (NPF) merupakan pembiayaan bermasalah, sehingga terjadi keterlambatan dalam pembayaran angsuran. Hal ini sangat mempengaruhi profitabilitas (ROA) suatu bank umum syariah. NPF (risiko pembiayaan) pun berkaitan dengan pembiayaan bank syariah kepada nasabahnya. Semakin tinggi NPF (risiko pembiayaan) maka pendapatan akan menurun, dan hal ini

${ }^{51}$ Fernando Africano. Pengaruh NPF Terhadap CAR Serta Dampaknya Terhadap Profitabilitas Bank Umum Syariah Di Indonesia. Forum Bisnis Dan Kewirausahaan Jurnal Ilmiah STIE MDP Vol. 6 No. 1 September 2016.

52 Komang Triska Ariwidanta. 2016. Pengaruh Risiko Kredit terhadap Profitabilitas dengan Kecukupan Modal sebagai Variabel Mediasi. E-Jurnal Manajemen Unud, Vol. 5, No. 4, 2016: 2311-2340 ISSN : 2302-8912.

${ }^{5}$ Ni Putu Sinta Wira Putri, I Made Dana. Pengaruh NPL, Likuiditas, dan Rentabilitas terhadap CAR Pada BPR Konvensional Skala Nasional di Indonesia. E-Jurnal Manajemen Unud, Vol. 7, No. 4, 2018: 18621891 ISSN : 2302-8912.

${ }^{54}$ Ni Putu Sinta Wira Putri, I Made Dana. Pengaruh NPL, Likuiditas, dan Rentabilitas terhadap CAR Pada BPR Konvensional Skala Nasional di Indonesia. E-Jurnal Manajemen Unud, Vol. 7, No. 4, 2018: 18621891 ISSN : 2302-8912. 
menyebabkan tingkat keuntungan bank akan mengalami penurunan. ${ }^{55}$ Hal ini diperkuat dengan hasil penelitian yang dilakukan oleh Nurismalatri ${ }^{56}$, serta Yuwita Ariessa Pravasanti ${ }^{57}$.

Didasarkan hasil perhitungan, diperoleh hasil penelitian nilai t hitung $>\mathrm{t}$ tabel $(2,131$ $>$ 1,66412) dan nilai signifikansi sebesar $0,036<0,05$, maka dapat disimpulkan bahwaLikuiditas (FDR) berpengaruh positif dan signifikan terhadap Profitabilitas (ROA) pada 7 Bank Umum Syariah periode 2016-2018. Likuiditas (FDR) merupakan kemampuan bank syariah dalam menyediakan dana dan menyalurkan dana kepada nasabah, dan memiliki pengaruh terhadap ROA (profitabilitas). Apabila bank syariah mampu menyediakan dana dan menyalurkan dana kepada nasabah secara tepat, maka akan meningkatkan return yang didapat dan berpengaruh terhadap meningkatnya ROA (profitabilitas) yang akan diperoleh oleh bank syariah tersebut. Hal ini menunjukkan adanya pengaruh positif yang berarti bahwa setiap peningkatan terhadap likuiditas akan diikuti juga dengan peningkatan terhadap profitabilitas. ${ }^{58} \mathrm{Hal}$ ini diperkuat dengan hasil penelitian yang dilakukan oleh Muhammad Yusuf, Surachman Surjaatmadja ${ }^{59}$, serta Yudhistira Ardana ${ }^{60}$.

Didasarkan hasil perhitungan, diperoleh hasil penelitian nilai t hitung $>\mathrm{t}$ tabel $(1,868$ $>1,66412$ ) dan nilai signifikansi sebesar 0,065 > 0,05, maka dapat disimpulkan bahwa Kecukupan Modal (CAR) tidak berpengaruh terhadap Profitabilitas (ROA) pada 7 Bank Umum Syariah periode 2016-2018. Kecukupan Modal (CAR) merupakan kemampuan bank syariah dalam menyediakan modal sehingga mampu memperoleh keuntungan. Semakin tinggi modal disuatu bank syariah maka nilai ROA (profitabilitas) akan mengalami peningkatan. Kenaikan nilai CAR (kecukupan modal) yang tidak diimbangi oleh kenaikan pembiayaan yang baik, maka laba yang dihasilkan tidak baik. Naik dan turunnya nilai CAR (kecukupan modal) mempengaruhi laba, ini menunjukkan bahwa Kecukupan Modal (CAR) berpengaruh positif dan tidak signifikan terhadap Profitabilitas (ROA). ${ }^{61}$ Hal ini diperkuat dengan hasil penelitian yang dilakukan oleh Rifka Nurul Izzah, Ahmad Mulyadi Kosim, dan

55 Dr. Irwan Ch. 2017.The Effect Of Financial Ratios On Islamic Rural Bank Performance In Indonesia. International Journal Of Scientific \& Technology Research Volume 6, ISSUE 08, August 2017. ISSN 2277-8616, hlm. 389

56 Nurismalatri. 2019. Sharia Banks’ Performance in Indonesia: A Panel Model Approach. Jurnal Sekuritas, Vol.2, No.2 , Januari 2019. ISSN (online) : 2581-2777 \& ISSN (print) : 2581-2696.

${ }^{57}$ Yuwita Ariessa Pravasanti. Pengaruh NPF dan FDR terhadap CAR dan Dampaknya terhadap ROA Pada Perbankan Syariah di Indonesia. Jurnal Ilmiah Ekonomi Islam, 4(03), 2018, 149, ISSN: $2477-6157$; EISSN 2579-6534.

${ }^{58}$ Muhammad Yusuf. 2017. Dampak Indikator Rasio Keuangan terhadap Profitabilitas Bank Umum Syariah di Indonesia. Jurnal Keuangan dan Perbankan, Vol 13 No. 2 Juni 2017: 141-151 ISSN: 1829-9865, hlm. 149.

59 Muhammad Yusuf dan Surachman Surjaatmadja.Analysis of Financial Performance on Profitability with Non Performance Financing as Variable Moderation (Study at Sharia Commercial Bank in Indonesia Period 2012-2016).International Journal of Economics and Financial Issues, 2018, 8(4), $126-132$. ISSN: 2146-4138.

60 Yudhistira Ardana. 2018. Faktor Eksternal dan Internal yang Mempengaruhi Profitabilitas Bank Syariah di Indonesia. Cakrawala: Jurnal Studi Islam Vol. 13 No. 1 (2018) pp. 51-59. pISSN: $1829-8931$. eISSN: 2550-0880.

${ }^{61}$ Saleh Sitompul dan Siti Khadijah Nasution. 2019. The Effect of Car, BOPO, NPF, and FDR on Profitability of Sharia Commercial Banks in Indonesia. Budapest International Research and Critics InstituteJournal (BIRCI-Journal) Volume 2, No 3, August 2019, Page: 234-238 e-ISSN: 2615-3076(Online), p-ISSN: 2615-1715. 
Syarifah Gustiawati ${ }^{62}$, serta Dr. Irwan $\mathrm{Ch}^{63}$.

Pengujian Variabel Mediasi dengan Causal Step

Gambar 1.2.

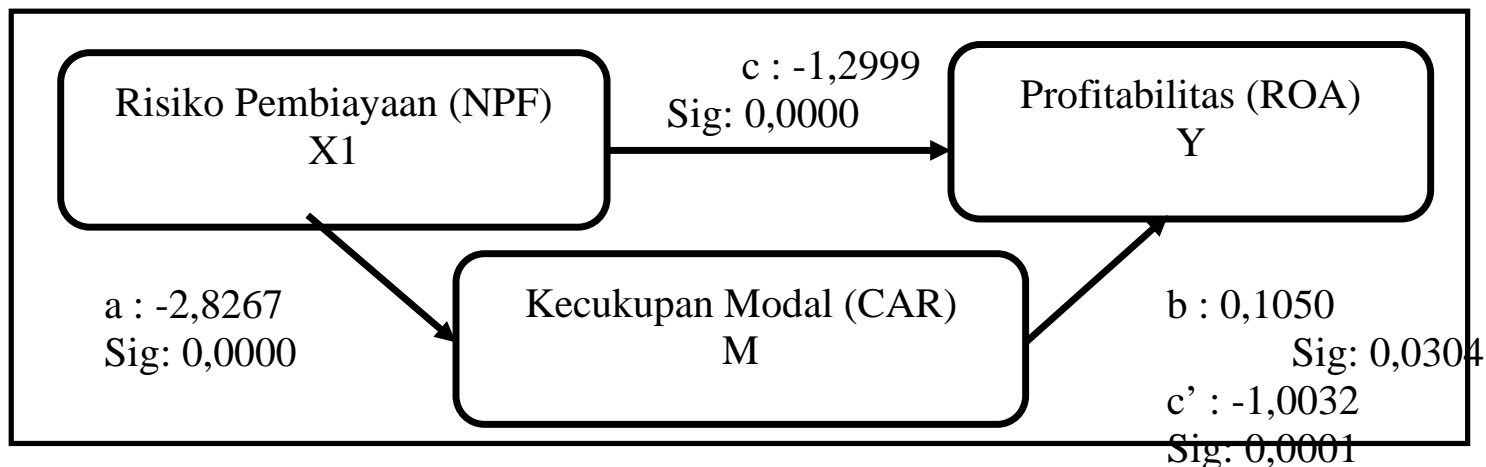

Koefisien a dan b yang signifikan sudah cukup untuk menunjukkan adanya mediasi, meskipun c tidak signifikan. Bila koefisien c' tidak signifikan maka terjadi full mediation. Bila koefisien c' berkurang namun tetap signifikan maka dinyatakan terjadi partial mediation atau terjadi mediasi. atau terjadi mediasi, dimana variabel Risiko Pembiayaan mampu mempengaruhi secara langsung variabel Profitabilitas maupun tidak langsung dengan melibatkan variabel intervening Kecukupan Modal, atau dapat dikatakan bahwa Kecukupan Modal memediasi Risiko Pembiayaan terhadap Profitabilitas.

Gambar 1.3.

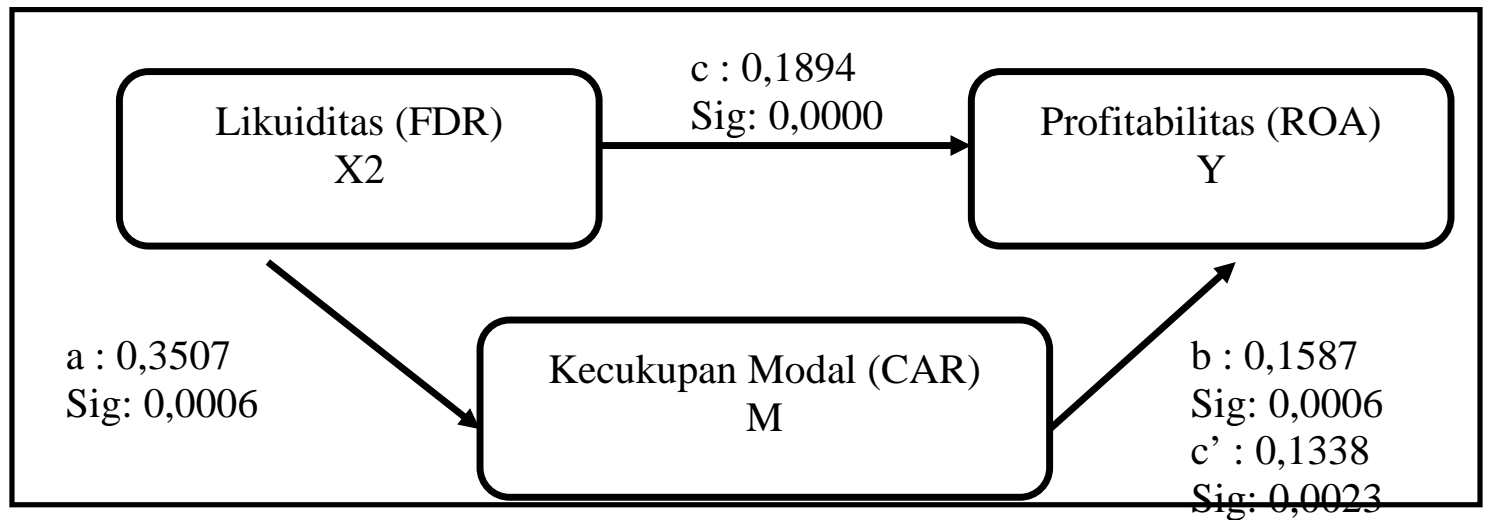

Koefisien a dan b yang signifikan sudah cukup untuk menunjukkan adanya mediasi, meskipun c tidak signifikan. Bila koefisien c' tidak signifikan maka terjadi full mediation. Bila koefisien c' berkurang namun tetap signifikan maka dinyatakan terjadi partial mediation atau terjadi mediasi. atau terjadi mediasi, dimana variabel Likuiditas mampu mempengaruhi secara langsung variabel Profitabilitas maupun tidak langsung dengan melibatkan variabel intervening Kecukupan Modal, atau dapat dikatakan bahwa Kecukupan Modal memediasi hubungan antara Likuiditas terhadap Profitabilitas.

62 Rifka Nurul Izzah, Ahmad Mulyadi Kosim, dan Syarifah Gustiawati. 2019. Pengaruh Non Performing Financing Dan Capital Adequacy Ratio Terhadap Profitabilitas. Al Maal: Journal of Islamic Economics and Banking. E-ISSN: 2580-3816.

63 Dr. Irwan Ch. 2017.The Effect Of Financial Ratios On Islamic Rural Bank Performance In Indonesia. International Journal Of Scientific \& Technology Research Volume 6, ISSUE 08, August 2017. ISSN 2277-8616. 


\section{Kesimpulan}

Adapun kesimpulan dan hasil penelitian adalah sebagai berikut:

1. Risiko Pembiayaan (NPF) berpengaruh negatif dan signifikan terhadap Kecukupan Modal (CAR).

2. Likuiditas (FDR) tidak berpengaruh terhadap Kecukupan Modal (CAR).

3. Risiko Pembiayaan (NPF) berpengaruh negatif dan signifikan terhadap Profitabilitas (ROA).

4. Likuiditas (FDR) berpengaruh positif dan signifikan terhadap Profitabilitas (ROA).

5. Kecukupan Modal (CAR) tidak berpengaruh terhadap Profitabilitas (ROA).

6. Kecukupan Modal (CAR) memediasi Risiko Pembiayaan (NPF) terhadap Profitabilitas (ROA).

7. Kecukupan Modal (CAR) memediasi Likuiditas (FDR) terhadap Profitabilitas (ROA).

\section{Daftar Pustaka}

\section{Buku:}

Dendawijaya, Lukman. 2005. Manajemen Perbankan, Edisi Kedua, Cetakan Kedua. Jakarta: Ghalia Indonesia

DR. Andri Soemitra,M.A. 2016. Bank dan Lembaga Keuangan Syariah Edisi Kedua. Jakarta: Kencana

Dr. Kasmir, SE., M.M. 2011. Kewirausahaan. Jakarta: PT RajaGrafindo Persada

Dr. Suliyanto. 2011. Ekonometrika Terapan: Teori \& Aplikasi dengan SPSS. Yogyakarta: Penerbit ANDI

Eungene F Brigman dan Joel F Houaton. 2001. Manajemen Keuangan. Jakarta: Erlangga

Ghozali, Imam. Model Persamaan Structural Konsep dan Aplikasi dengan Program AMOS Ver. 5.0. Semarang: Badan Penerbit Universitas Diponegoro

Ghozali, Imam. 2007. Aplikasi Analisis Multivariate dengan Program SPSS. Semarang: UNDIP

Ismail Nawawi Uha. 2011. Manajemen Risiko. Sidoarjo: Star Safira

Kasmir. 2012. Bank dan Lembaga Keuangan Lainnya. Jakarta: RajaGrafindo Persada

Kasmir. 2014. Analisis Laporan Keuangan, Edisi Satu, Cetakan Ketujuh. Jakarta: PT. Raja Grafindo Persada

Lidia Desiana, S.E, M. Si dan Aryanti, MM. 2017. Manajemen Keuangan Bank Syariah (Teori dan Evaluasi). Palembang: Penerbit Noer Fikri

Lidia Desiana, S.E, M. Si dan Fernando Africano, SEI., M.Si. 2017. Analisis Laporan Keuangan (Teori dan Pemahaman Materi). Palembang: Penerbit Noer Fikri

Martono, Nanang. 2014. Metode Penelitian Kuantitatif: Analisis Isi dan Analisis Data Sekunder. Jakarta: PT. RajaGrafindo Persada

Muhamad. 2014. Manajemen Dana Bank Syariah. Yogyakarta: Raja Grafindo Persada

Noor Juliansyah. 2011. Metodologi Penelitian: Skripsi, Tesis, Disertasi dan Karya Ilmiah. Jakarta: Kencana

Preacher, K. J., Rucker, D. D and Hayes, A. F. “ Addressing Moderated Mediation Hypothesis: Theory, Methods and Prescriptions”. (Multivariate Behavioral Research, 42(1), 185227.Lawrence Erlbaum Associates, Inc. 2007)

Riyanto, Bambang. 2008. Dasar-Dasar Pembelajaran Perusahaan. BPFE: Yogyakarta 
Sugiyono. 2014. Metode Penelitian Kuantitatif, Kualitatif dan R\&D. Bandung: Alfabeta Supriyono. 1999. Manajemen Biaya Suatu Reformasi Pengelolaan Bisnis Buku I Edisi I. Yogyakarta: BPFE

Syafri Harahap, Sofyan. 2008. Analisa Kritis atas Laporan Keuangan. Jakarta: PT. Raja Grafindo Persada

Weston J.Fred.dan Eugene F. Brigham. 2001. Dasar-Dasar Manajemen Keuangan. Jakarta: Erlangga

Zainul Arifin. 2005. Dasar-Dasar Manajemen Bank Syariah. Jakarta: Pustaka Alvabet

\section{Jurnal:}

Baron, R. M and Kenny, D. A. "The Moderator-Mediator Variable Distinction In Social Psychological Research: Conceptual Strategic and Statistical Considerations.” Journal of Personality and Social Psychologi. Vol. 51, No. 6, 1173-1182. Americal Pshcological Association, Inc. 1986

Chairul Adhim. 2018. Pengaruh Risiko Kredit, Risiko Likuiditas, Efisiensi Manajemen Terhadap Profitabilitas Melalui Permodalan. Jurnal Bisnis dan Manajemen Vol. 5 No. 1, Januari, 2018, p 1-10, p-ISSN: 1829-7528, e-ISSN: 2581-1584

Dr. Irwan Ch. 2017. The Effect Of Financial Ratios On Islamic Rural Bank Performance In Indonesia. International Journal Of Scientific \& Technology Research Volume 6, ISSUE 08, August 2017. ISSN 2277-8616

Farida Shinta Dewi, Rina Arifati, Rita Andini. 2016. Analysis of Effect Of CAR, ROA, LDR, Company Size, NPL, and GCG to Bank Profitability (Case Study on Banking Companies Listed In BEI Period 2010-2013). Journal Of Accounting, Volume 2 No.2 Maret 2016

Fernando Africano. Pengaruh NPF Terhadap CAR Serta Dampaknya Terhadap Profitabilitas Bank Umum Syariah Di Indonesia. Forum Bisnis Dan Kewirausahaan Jurnal Ilmiah STIE MDP Vol. 6 No. 1 September 2016

Komang Triska Ariwidanta. 2016. Pengaruh Risiko Kredit terhadap Profitabilitas dengan Kecukupan Modal sebagai Variabel Mediasi. E-Jurnal Manajemen Unud, Vol. 5, No. 4, 2016: 2311-2340 ISSN : 2302-8912

Muhammad Yusuf. 2017. Dampak Indikator Rasio Keuangan terhadap Profitabilitas Bank Umum Syariah di Indonesia. Jurnal Keuangan dan Perbankan, Vol 13 No. 2 Juni 2017: 141-151 ISSN: 1829-9865

Muhammad Yusuf dan Surachman Surjaatmadja. Analysis of Financial Performance on Profitability with Non Performance Financing as Variable Moderation (Study at Sharia Commercial Bank in Indonesia Period 2012-2016). International Journal of Economics and Financial Issues, 2018, 8(4), 126-132. ISSN: 2146-4138

Ni Putu Sinta Wira Putri, I Made Dana. Pengaruh NPL, Likuiditas, dan Rentabilitas terhadap CAR Pada BPR Konvensional Skala Nasional di Indonesia. E-Jurnal Manajemen Unud, Vol. 7, No. 4, 2018: 1862-1891 ISSN : 2302-8912

Nurismalatri. 2019. Sharia Banks' Performance in Indonesia: A Panel Model Approach. Jurnal Sekuritas, Vol.2, No.2 , Januari 2019. ISSN (online) : 2581-2777 \& ISSN (print) : 2581-2696

Rifka Nurul Izzah, Ahmad Mulyadi Kosim, dan Syarifah Gustiawati. 2019. Pengaruh Non Performing Financing Dan Capital Adequacy Ratio Terhadap Profitabilitas. Al Maal: Journal of Islamic Economics and Banking. E-ISSN: 2580-3816 
Saleh Sitompul dan Siti Khadijah Nasution. 2019. The Effect of Car, BOPO, NPF, and FDR on Profitability of Sharia Commercial Banks in Indonesia. Budapest International Research and Critics Institute-Journal (BIRCI-Journal) Volume 2, No 3, August 2019, Page: 234-238 e-ISSN: 2615-3076(Online), p-ISSN: 2615-1715

Triyani.2018. Pengaruh Financing To Deposit Ratio (FDR) dan Office Channeling terhadap Profitabilitas Unit Usaha Syariah Periode 2015-2017. Skripsi Universitas Islam Negeri Raden Intan Lampung

Yudhistira Ardana. 2018. Faktor Eksternal dan Internal yang Mempengaruhi Profitabilitas Bank Syariah di Indonesia. Cakrawala: Jurnal Studi Islam Vol. 13 No. 1 (2018) pp. 51-59. pISSN: 1829-8931. eISSN: 2550-0880

Yuwita Ariessa Pravasanti. Pengaruh NPF dan FDR terhadap CAR dan Dampaknya terhadap ROA Pada Perbankan Syariah di Indonesia. Jurnal Ilmiah Ekonomi Islam, 4(03), 2018, 149, ISSN: 2477-6157 ; E-ISSN 2579-6534

\section{Website:}

www.ojk.go.id (Laporan Keuangan Rasio Bank Umum Syariah) 